

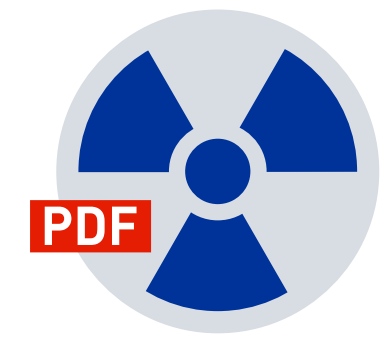

\section{REALOBJECTS PDFreactor $^{\oplus}$}

\section{Evaluation Version}

This PDF document was created by an evaluation version of RealObjects PDFreactor 10.2.10722. The evaluation version is fully functional, but includes this information page. It must not be used for production purposes. The information page and all other evaluation notices must not be removed from the PDF file.

NOTE: Conversions in evaluation mode might be slower and the results might have a larger file size than in production mode.

\section{Buy PDFreactor}

PDFreactor has detected 4 CPU cores, which means you need 1 license pack to use PDFreactor.

To buy a PDFreactor license follow this link:

\section{Buy PDFreactor online}

\section{About PDFreactor}

RealObjects PDFreactor is a powerful formatting processor for converting HTML and XML documents into PDF. It uses Cascading Style Sheets (CSS) to define page layout and styles. The server-side tool enables a great variety of applications in the fields of ERP, eCommerce and Electronic Publishing.

PDFreactor supports HTML5, CSS3 and JavaScript.

It allows you to dynamically generate PDF documents such as invoices, delivery notes and shipping documents on-the-fly. PDFreactor allows you to easily add server-based PDF generation functionality to your application or service. Since PDFreactor runs on a server, the end-user in general does not need any software other than a PDF viewer.

For more information visit www.pdfreactor.com 

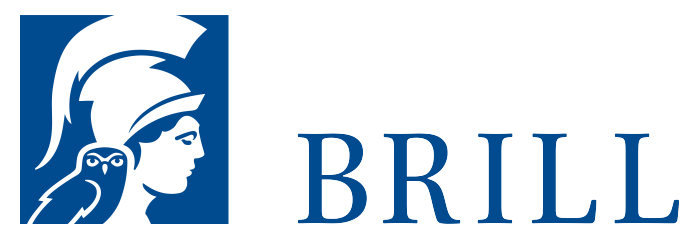

\title{
Studies in Jewish and Christian History, Volume 1
}

\author{
Author: Elias J. Bickerman
}

For more information see brill.com

Order information: Order online at brill.com +44330 333 0049 | customerservices@brill.com Submission information: brill.com/authors

Titles published by Brill | Fink, Brill | mentis or Brill | Schöningh: +49(o)715413279216| brill@brocom.de

Pages: xvi, 392 pp. frontisp.

Language: English

Subjects: Early Church \& Pa Studies

Publisher: Brill

Series:

Arbeiten zur Geschichte des Judentums und des Urchristı $9 / 1$

\section{E-Book (PDF)}

Released online: $17 \mathrm{Jul} 2018$

ISBN: 978-90-04-33260-7

\section{List price}

USD \$230.00

Hardback

Publication date: o1 Dec 197 ISBN: 978-90-04-04396-1 